\title{
I
}

\section{CONSTRUÇÃO E DESCONSTRUÇÃO DO TRABALHO NO BRASIL: DA CONCILIAÇÃO AO GOLPE*1}

\author{
Ricardo Antunes \\ Marco Aurélio Santana \\ Luci Praun
}

\section{Introdução}

Após um período de estabilidade e crescimento na primeira década dos anos 2000, o Brasil entrou em um ciclo de profunda crise econômica, social, política e institucional. Assim como seu período de bonança deveu-se, em grande medida, às condições internacionais, as causas mais profundas da atual crise brasileira possuem fortes componentes globais. Elas são parte do movimento efetuado pelo capitalismo, nas últimas décadas do século XX, em busca por impulsionar seus ciclos de acumulação e desviar-se, mesmo que temporariamente, de seus próprios limites, expressos em crises com profunda repercussão mundial. $\mathrm{Na}$ era em que a mundialização e financeirização do capital atingiram seu ponto alto, essas crises têm se tornado, ao redor do globo, mais frequentes e profundas.

O advento da crise de 2008 e seu impacto nos diferentes países do globo é parte desse processo. Inicialmente, atingiu os países capitalistas centrais, como Estados Unidos, Japão, Alemanha, Inglaterra, França, Itália, entre outros. Mas, dada sua conformação global, desigual e combinada, projetou-se para as diversas nações do mundo asiático, atingindo também países de desenvolvimento intermediário, como os que compõem o chamado BRICS (Brasil, Rússia, Índia, China e África do Sul) e, mais acentuadamente, o conjunto da periferia do sistema.

${ }^{*}$ DOI - 10.29388/978-65-86678-40-6-0-f.23-56

${ }^{1}$ Este capítulo é uma versão, com algumas alterações, de Chronicle of a Defeat Foretold: The PT Administrations from Compromise to the Coup, Latin American Perspectives, V.1, p. 85-104, January 1, 2019. ISSN 0094-582X. 
As repercussões da crise no Brasil, considerada de início como "marolinha" pelo governo, foram pouco a pouco solapando o projeto do Partido dos Trabalhadores (PT), vigente desde 2003, com a posse de Luiz Inácio da Silva, o Lula. Implantado ao longo dos dois mandatos presidenciais consecutivos de Lula e, a partir de 2011, por sua sucessora, Dilma Rousseff, o projeto começou a dar sinais claros de desmoronamento em 2013, quando as rebeliões de rua atingiram, em junho, seu ápice.

Esta clara fadiga do projeto, acentuada pela persistência e aprofundamento da crise econômica mundial, levaria para as ruas um amplo setor da juventude trabalhadora. Submetida à crescente precariedade do mercado de trabalho, impossibilitada do acesso à educação de qualidade, deixada à mercê de um sistema público de saúde sucateado, e sem qualquer segurança sobre o futuro, o aumento das tarifas do transporte coletivo converteu-se numa espécie de catalisador do descontentamento dessa camada de jovens.

Em sua essência, a movimentação desses jovens e a forte onda grevista que o país vivenciou no mesmo ano refletiam a falência de um projeto que, apesar de brotar das esperanças e desejos de muitos por mudanças, não foi capaz de realizá-las, mostrando rapidamente seus limites e contradições. A realidade brasileira começava então a ser desnudada em profundidade e, com ela, independentemente do que seriam os avanços logrados, o fracasso social e político dos governos do PT.

Quais foram os principais componentes das políticas desenvolvidas pelo PT, com impacto nos direitos sociais e do trabalho, entre 2003 e 2016 ? Elas trouxeram prevalentemente elementos positivos e de avanço ou negativos e de limitações? Elas acabaram por resultar em uma vitória das forças sociais do trabalho ou em um fracasso que amplificou a crise profunda que se abateu nos governos do PT? O objetivo deste capítulo é oferecer um balanço crítico desta experiência, de modo a apresentar algumas respostas a estas indagações.

\section{Da confrontação à concertação}

O Brasil teve um papel de destaque nas lutas operárias e sindicais na década de 1980, conseguindo retardar a implantação do neoliberalismo, que já se expandia por vários países da América Latina, como Chile, Argentina, México, entre outros. Enquanto nos países do Norte, o neoliberalismo deslanchava, no Brasil, naquela década, caminhávamos na contramão destas tendências re- 
gressivas. Assim, se para o capital esta foi considerada uma "década perdida", para os movimentos sindicais e populares, esta foi uma "década vitoriosa".

Depois das históricas greves do ABC Paulista, em fins da década de 1970, com a emergência do chamado "novo sindicalismo", as greves generalizaram-se pelo país, atingindo amplos contingentes da classe trabalhadora. Ampliaram-se sobremaneira os sindicatos de classe e os incontáveis movimentos sociais, o que significou um período de disseminação de lutas sociais e políticas de grande envergadura (SANTANA, 1999; ANTUNES, 2004, 2006b, 2015; PRAUN, 2005, 2006, 2012; ANTUNES, SANTANA, 2014).

Em curto espaço de tempo, indicando a pujança organizativa e mobilizatória da classe trabalhadora, a década de 1980 impulsionaria também, como parte da intensa mobilização social no país, a fundação e crescimento de um partido de extração operária e sindical, o PT, e da Central Única dos Trabalhadores (CUT). Produziria ainda, paulatinamente, a crescente inserção de parcela importante de seus militantes e ativistas sindicais nas estruturas do Estado brasileiro.

As vitórias eleitorais alcançadas pelo PT, se por um lado refletiram a consolidação de uma base social em grande medida forjada nas mobilizações sociais da década de 1980, também se converteram em ponto de apoio importante para o fortalecimento de uma prática política que passou a se caracterizar, na década de 1990, pela preocupação em formular propostas consideradas viáveis institucionalmente, mais "propositivas", como se dizia então.

As avaliações da direção majoritária do PT sobre as razões da derrota da candidatura de Lula nas eleições presidenciais de 1989 acentuariam essa tendência, expressa nos anos seguintes, entre outras iniciativas, na participação da CUT, em 1992 e 1993, nas Câmaras do Setor Automotivo (GALVÃO, 1996; PRAUN, 2012). Essa participação deixava evidente a busca não somente por demonstrar postura ativa na "[...] elaboração de uma política industrial em bases democráticas [...]", conforme defendia na ocasião o Sindicato dos Metalúrgicos do ABC (1992, p. 5), mas a disposição de chegar ao poder central, pela via institucional, e sem colocar em risco a ordem e a estrutura social estabelecida. Essa disposição pôde ser observada com maior clareza dez anos depois, durante a eleição de 2002, que resultou no primeiro mandato presidencial de Lula. Durante a disputa eleitoral, o PT publicou a "Carta ao Povo Brasileiro" (SILVA, 2002), assinada por Lula, na qual foram dadas as garantias ao mercado financeiro de uma política futura de controle da economia e de respeito aos "contratos e obrigações do país". 
Durante os anos que separaram as experiências com as Câmaras Setoriais e as eleições de 2002, medidas de flexibilização da produção e do trabalho (institutição dos bancos de horas e de dias; adoção de mecanismos voltados ao trabalho polivalente e multifuncional; redução do piso de ingresso de categorias profissionais; flexibilização da remuneração por meio da política de participação nos resultados, entre outras) passaram a ser defendidas e incorporadas com frequência aos acordos coletivos assinados por sindicatos filiados à CUT, tendo como polo irradiador dessa prática o sindicalismo metalúrgico do ABC Paulista (PRAUN, 2005, 2006, 2012).

Durante a década de 1990, em meio ao fortalecimento do neoliberalismo e das medidas voltadas a reestruturar a produção e o trabalho, que devastariam o mundo do trabalho brasileiro, consolidaria-se no interior da CUT uma prática sindical centrada na apresentação de propostas "viáveis", que buscassem evitar o confronto entre capital e trabalho, privilegiando a negociação em detrimento da mobilização. De forma decorrente, buscou-se a viabilização da vitória eleitoral por meio da construção de um pacto, articulando as diferentes frações da classe dominante, para a gestão do capitalismo brasileiro.

\section{Os governos Lula: o PT no poder}

Na ocasião da vitória eleitoral da candidatura de Lula, em 2002, após dois mandatos consecutivos de Fernando Henrique Cardoso (1994-2002), o Brasil havia se transformado em um país bastante diverso, agora inserido em um contexto nacional e internacional distinto daquele observado nas décadas anteriores. Isto porque a eleição de Lula ocorreu quando o transformismo (GRAMSCI, 1989) já vinha impregnando a prática política do PT, o que o transformou gradativamente em uma variante de Partido da Ordem (MARX, 1974), cada vez mais moderado e institucionalizado em seus métodos, práticas e ações.

Quando de sua primeira candidatura em 1989, Lula e o PT, assentados em um movimento aguerrido e em ascenso, tinham um programa agudo de mudanças que foi derrotado nas urnas. Em 2002, em meio a um mundo do trabalho e movimento dos trabalhadores devastado, e em aliança com setores conservadores, Lula e o PT saem vitoriosos das urnas.

O neoliberalismo, que se desenvolveu nos anos 1990 com Fernando Collor (1990-1992) e FHC, havia desertificado em boa medida o país, e o PT já 
não era mais um partido centralmente voltado para os interesses da classe trabalhadora. Oscilava cada vez mais entre a resistência ao neoliberalismo e a aceitação e defesa de uma nova pragmática, mais policlassista. ${ }^{2}$

O primeiro governo Lula, com início em janeiro de 2003, foi caracterizado, então, mais pela continuidade do que pela ruptura com o neoliberalismo, uma vez que também desenvolveu políticas com claras semelhanças àquelas propostas pelo social-liberalismo, que floresceram a partir do experimento realizado pelo New Labour de Tony Blair. ${ }^{3}$

Vale destacar que, ao longo do primeiro mandato, a política econômica desenvolvida por Lula jamais questionou a hegemonia dos capitais financeiros. Longe disso, seguiu rigorosamente os pilares indicados pelo FMI, mantendo, desse modo, os elementos estruturais que preservavam o capitalismo e que particularizavam nossa formação social burguesa.

Como indicou o próprio Lula em comício realizado em Fortaleza, durante as eleições municipais de 2012, "Eu às vezes fico pensando por que as pessoas criticam tanto o Lula. Veja, se dependesse de ganhar dinheiro, os empresários desse país todo dia tinham que acender uma vela pra Deus porque nunca ganharam tanto dinheiro como ganharam no meu governo" (CABRAL, 2012). Lula agrega ao seu discurso que teria sido este o caminho que possibilitou os avanços em termos de ampliação do número de empregos formais no país.

Quais foram as políticas balizadoras dos governos do PT? Passemos agora a analisar mais de perto algumas delas. Levaremos em conta, em termos de limites, possibilidades e contradições, as políticas relativas ao emprego, aos sindicatos e ao combate à pobreza. $\mathrm{Na}$ parte final, analisaremos o desfecho dos governos do PT com o golpe parlamentar-jurídico-midiático que pôs fim aos seus quatorze anos de experiência no executivo federal.

\section{A política de empregos}

A vitória de Lula, apesar da ampla aliança que o apoiou, abriu um sem número de expectativas acerca das mudanças estruturais por ele prometidas de há muito. Contudo, o processo eleitoral se deu em meio aos prenúncios de uma

\footnotetext{
${ }^{2}$ Retomamos aqui várias ideias que estão apresentadas especialmente em Antunes (2004, 2006b, 2015).

${ }^{3}$ Ver o rico e abrangente balanço crítico do neoliberalismo e suas distintas variantes em Pradella e Marois (2015).
} 
crise econômica. Diante da possibilidade de vitória de Lula, parte do investimento voltado à especulação financeira ameaçou sair do país. Com a "Carta aos brasileiros" (SILVA, 2016), como já indicamos, Lula buscou tranquilizar o mercado indicando que as bases da estabilização seriam mantidas.

O governo Lula, em seus dois mandatos (2003-2006 e 2007-2010), seguiu de muito perto a política econômica do governo anterior, ainda que nuançada por uma perspectiva social-liberal. Entre outras medidas, preservou os interesses do capital financeiro, por meio da manutenção do superávit primário. No que se refere à legislação trabalhista, além da introdução da cobrança de contribuição previdenciária dos aposentados - que lhe gerou uma enorme dissensão no sindicalismo dos trabalhadores públicos, um dos pilares constitutivos da CUT em sua origem -, tentou, ao final do primeiro mandato, viabilizar uma ampla reforma sindical e trabalhista, apesar da forte oposição tanto de sindicatos e centrais sindicais patronais quanto daquelas entidades vinculadas aos trabalhadores (ANTUNES, 2006b, 2014; GALVÃO, 2007).

Dada a conjuntura internacional, foi acumulando índices econômicos positivos. De forma geral, o governo Lula caracterizou-se pela baixa inflação e pela redução do desemprego. Ainda que seja preciso discutir o tipo e a qualidade dos empregos criados, neste quesito são dados que chamam a atenção. No período compreendido entre os anos 1998 e 2007, obteve-se uma taxa de crescimento do emprego de 56\%. Em 1998, o mercado formal brasileiro contava com 24,5 milhões de empregos. Este total subiu, em 2002, para o patamar de 28,7 milhões, chegando a 37,6 milhões em 2007. Os melhores resultados obtidos neste campo foram auferidos entre 2003 e 2007, quando a maioria destes empregos foi criada e o nível de desemprego registrou queda bastante sensível, passando de uma taxa de 12\%, em 2003, para 9\%, em 2007 (SANTANA, 2012).

Quando a crise mundial atingiu fortemente os países capitalistas centrais, o governo Lula tomou medidas visando incentivar, por meio da ação estatal, a retomada do crescimento econômico através da ampliação do mercado interno. Para tal, entre outras medidas, o governo reduziu impostos nos setores automobilístico, eletrodoméstico e de construção civil, todos de forte incorporação de força de trabalho.

Se, conforme aponta Pochmann (2012), na década de 1990 atravessamos um período de forte redução nos empregos formalizados, ${ }^{4}$ na década se-

\footnotetext{
${ }^{4}$ Segundo Pochmann, “[...] foram criados 11 milhões de empregos, dos quais 53,6\% não previam remuneração. $\mathrm{Na}$ faixa de renda de até 1,5 salário mínimo houve a redução líquida de quase 300 mil postos de trabalho" (idem, p. 27).
} 
guinte, sob os governos de Lula e início do primeiro mandato de Dilma, foram criados 21 milhões de postos, o que atesta a ampla incorporação de trabalhadores e trabalhadoras ao mercado de trabalho.

A expansão dos postos de trabalho, entretanto, guardou particularidades. É preciso destacar que $94,8 \%$ de trabalhadores incorporados ao mercado formal percebiam uma baixa remuneração (1,5 salário mínimo por mês). As atividades que mais cresceram ao longo deste período foram: serviços, com 6,1 milhões de novos empregos; seguidos pelos trabalhadores do comércio, com 2,1 milhões; da construção civil, com 2 milhões; de escriturários, com 1,6 milhões; da indústria têxtil e vestuário, com 1,3 milhão, e do setor público, com 1,3 milhão (POCHMANN, 2012; ANTUNES, 2014).

Como afirma Pochmann (2012, p. 32), estas profissões totalizaram "[...] 14,4 milhões de novos postos de trabalho, o que equivaleu a $72,4 \%$ de todas as ocupações com remuneração também de até 1,5 salário mínimo mensal". Vale ainda acrescentar que foi significativa a ampliação do trabalho feminino, chegando a quase $60 \%$ das ocupações, com concentração entre mulheres na faixa de 25 a 34 anos.

A precariedade e o nível de degradação do trabalho também puderam ser evidenciados a partir de outros indicadores que fornecem uma visão panorâmica do mercado de trabalho brasileiro. Ao longo do governo Lula, conforme destaca Braga (2015),

[...] o número de acidentes e mortes no trabalho cresceu e a taxa de rotatividade do emprego aumentou [...]. E como seria diferente se os principais motores do atual regime de acumulação pós-fordista e financeirizado são a indústria da construção pesada e civil, a agroindústria e o setor de serviços? Além disso, apesar do crescimento econômico recente, a estrutura social brasileira não superou sua condição semiperiférica, o que implica a combinação de um grande número de empregos baratos com um baixo índice de investimento em ciência e tecnologia, fortalecendo o despotismo empresarial.

Observado todo este quadro, deve-se dizer que os governos do PT conseguiram aumentar o número de trabalhadores/as empregados e formalizados, e assim reduzir os índices de desemprego, contudo, não conseguiram eliminar as condições de vulnerabilidade que acentuam a precarização da força de trabalho no Brasil, exemplificados nos altos índices de informalidade e nos crescentes contingentes de terceirização. Assim, a desregulamentação e a ampli- 
ação das formas de subcontratação se mantiveram, ainda que em patamares menores do que aqueles vigentes nos anos 1990.

Desse processo contraditório, o mais expressivo talvez tenha sido a enorme expansão do novo proletariado de serviços, que se desenvolveu em decorrência tanto da reestruturação produtiva como do significativo processo de privatização das empresas estatais e dos serviços públicos. A enorme expansão do trabalho em call centers e telemarketing, das empresas de tecnologias de informação e comunicação (TIC), dos hipermercados, da indústria hoteleira, etc., cada vez mais inseridas no processo de valorização do capital, gerou o nascimento de um novo proletariado de serviços, o infoproletariado ou o cybertariat (ANTUNES; BRAGA, 2009; HUWS, 2003).

Se ao longo da década de 1980 era relativamente pequeno o número de terceirizados (subcontratados), nas décadas seguintes esse número cresceu, constituindo um contingente expressivo de trabalhadores e trabalhadoras frequentemente sem vínculo empregatício e sem registro formalizado, padecendo de altos índices de rotatividade, por vezes à margem da legislação trabalhista, redesenhando a morfologia do trabalho no Brasil (ANTUNES, 2006b, 2014, 2015; DRUCK, 1999, 2011; DRUCK; FRANCO, 2007). ${ }^{5}$

Foi com essa programática (social, sindical e de empregos) que Lula implementou uma política policlassista de concertação e conciliação muito exitosa por um longo período, tendo forte apoio dos distintos setores do empresariado, beneficiando enormemente as diversas frações do grande capital, especialmente o financeiro e o industrial que, como sabemos, guardam forte simbiose entre si, ainda que por vezes tenham disputado espaços na condução da política econômica governamental, juntamente com o setor do agronegócio e das demais frações burguesas, todas partícipes do projeto lulista.

No ramo industrial, considerando apenas dois exemplos, vemos que o setor automotivo atingiu recordes sucessivos de produção, e a quase extinta indústria naval reapareceu de forma consistente no cenário, assumindo posição de destaque entre as maiores do mundo no setor (SANTANA, 2012).

5 Em estudo realizado pelo DIEESE, os setores considerados "tipicamente terceirizados" correspondiam a $25,5 \%$ dos empregos formais no Brasil, sendo sua remuneração $27,1 \%$ menor do que a dos demais empregados formalizados. No que concerne à jornada de trabalho, os terceirizados trabalham em media 3 horas a mais e o seu tempo de permanência no emprego é $55,5 \%$ menor do que o dos demais empregados. Sua taxa de rotatividade/turnover é de 44,9\%, enquanto nas demais empresas é de 22,0\% (DIEESE-CUT, 2011). Ver também Riqueza e Miséria do Trabalho, Vol. III, op. cit. 
No topo, os grandes capitais lucraram como poucas vezes na história recente do país, em praticamente todos os seus segmentos. Na base da pirâmide social, o governo do PT (e sua ampla coalização) implementou uma política social muito mais ampla que seus antecessores, ainda que de perfil predominantemente assistencialista, visando minimizar em alguma medida a miséria brasileira. Parcelas da base mais empobrecida e pauperizada da nossa pirâmide social puderam ascender alguns degraus, especialmente na esfera dos bens de consumo assalariado, à custa, entretanto, como se pôde constatar posteriormente, do seu enorme endividamento.

No que diz respeito ao salário mínimo, experimentou-se o seu maior crescimento real. Observou-se o crescimento da massa salarial real do trabalhador a partir de 2003. Esta massa ficou em níveis de estagnação no período 1998/2002, com valor de aproximadamente $\mathrm{R} \$ 36$ bilhões. A partir de 2003, assistimos o crescimento anual da mesma, indo, por exemplo, a patamares de $\mathrm{R} \$$ 52 bilhões em 2007. Tal situação teve claros impactos na recuperação do poder de compra das classes populares. Em números, em oito anos, o salário mínimo cresceu de $\mathrm{R} \$ 200$ para $\mathrm{R} \$ 510$, apresentando assim um aumento de cerca de 150\% (apesar de ser um salário mínimo muito baixo, quando comparado aos valores indicados pelo DIEESE) (SANTANA, 2012).

Assim, a política de preservação e ampliação do salário mínimo também permitiu que o seu segundo governo superasse a profunda crise do final de seu primeiro mandato e avançasse intensamente em seus níveis de popularidade. Mas é preciso enfatizar que nenhum dos pilares estruturantes da miséria brasileira foi efetivamente enfrentado. E este elemento de fundo se acentuou ao final do primeiro governo Dilma e início do seu segundo, quando a crise brasileira se intensificou.

É importante também demarcar as mediações desse processo. Por um lado, o governo do PT, predominantemente a partir de 2006, impulsionou políticas assistenciais, assim como o aumento real do salário mínimo e, apoiado nessas iniciativas, construiu sua base de apoio junto aos segmentos mais pauperizados da sociedade. Por outro, desde seu primeiro mandato, avançou na reforma da previdência e instituiu duas leis que atingiram os direitos trabalhistas (KREIN; BIAVASCHI, 2015).

A primeira delas, Lei 11.101, de 9/2/2005, institui, nas palavras de Souto Maior (2014, p. 5), o "calote trabalhista". Com as novas regras, em situações de recuperação judicial, extrajudicial e de falência de empresas, o crédito trabalhista deixa de ser prioridade frente aos demais. Somente créditos no limite 
de 150 salários mínimos mantêm-se prioritários frente aos demais. A Lei reforça, dessa forma, a lógica de distribuição entre o empregador e o trabalhador, dos riscos do negócio (SOUTO MAIOR, 2014).

A segunda, a Lei 10.820, de 17/12/2003, deu início ao processo de regulação do crédito consignado em folha de pagamento. Tal legislação, além de proteger as instituições financeiras, dando-lhes a segurança do recebimento de empréstimos e financiamentos com débito direto na folha de pagamento, forneceu sustentação a um programa de governo que, ao longo de muitos anos, viabilizou-se ancorado no incentivo ao consumo associado ao endividamento dos trabalhadores (KREIN; BIAVASCHI, 2015).

\section{A questão sindical}

Não por acaso, portanto, sob a condução de Lula e de seus formuladores, durante o primeiro governo do PT, em fins de 2004 e início de 2005, ganhou força a proposta de reforma sindical. A vitória eleitoral de Lula trouxe ao poder uma geração de militantes sindicais forjados, como ele, no chamado "novo sindicalismo" e na crítica à herança do chamado "peleguismo sindical". Promessa de campanha, a reforma da legislação sindical entrou na pauta. O Ministério do Trabalho, a partir da organização do Fórum Nacional do Trabalho (FNT), integrado, de forma tripartite, por representantes de trabalhadores, patronato e governo, procurou elaborar um novo projeto sindical para o país. ${ }^{6}$

Havia certa demanda sobre tais mudanças por parte dos setores sindicais desde os governos de FHC, que queria, junto com o patronato, efetivar uma reforma trabalhista sem fornecer aos sindicatos novas possibilidades de organização e mobilização que os libertassem dos controles dispostos na CLT.

$\mathrm{Na}$ visão de seus propositores no governo, a reforma seria um passo na direção de uma mudança mais ampla, projetada não somente como "mera alteração legislativa", mas como "[...] um amplo reordenamento jurídico-institucional de caráter sistêmico que, do ponto de vista normativo", visava “[...] envolver o Direito Sindical, a Legislação do Trabalho, o Direito Processual do Trabalho, os órgãos de Administração Pública do Trabalho e a Justiça do Trabalho" (MTE, 2005, s/d).

O conjunto de reformas nessa área, pretendidas pelo governo, segundo expresso em seus documentos (MTE, 2003; MTE, 2005), vinha no sentido de

${ }^{6}$ Para detalhes na montagem e funcionamento do FNT, ver, entre outros, Bargas e Oliveira (2005), Druck (2006) e Santana (2009). 
tornar as leis e instituições do trabalho mais compatíveis com o que seria a nova conjuntura social, política e econômica vividas pelo país. Em consonância com esses objetivos, a "Exposição de Motivos" do projeto assinalava que:

A Reforma da Legislação Sindical é um dos mais caros compromissos de mudança desta gestão, em função do atraso estrutural das normas vigentes. Permitir uma organização sindical realmente livre e autônoma em relação ao Estado, além de fomentar a negociação coletiva como instrumento fundamental para solução de conflitos, são objetivos essenciais para o fortalecimento da democracia e estímulo à representatividade autêntica (MTE, 2005, s/d).

No entanto, o anteprojeto de lei que tratou da questão, apesar de alguns pontos de consenso, gerou mais dissenso e muitas dúvidas. Chegou ao legislativo exatamente em um momento crítico da vida política nacional, marcado por escândalos protagonizados por figuras exponenciais do governo e do partido do presidente.

Obviamente utilizadas pela mídia e a oposição, produziu-se, a partir das denúncias de corrupção do chamado caso do "Mensalão", certa paralisia da vida legislativa enquanto tal, carreando energias para as Comissões Parlamentares de Inquérito (CPIs). O governo, também duramente impactado pelas denúncias, com margem estreita de ação, optou por fatiar o projeto de lei da reforma trabalhista, dando sequência, no varejo, apenas a alguns pontos como, por exemplo, o reconhecimento das centrais sindicais (SANTANA, 2009).

Ainda que essa proposta de reforma trabalhista tenha sido obstada tanto pela crise política, assim como pela forte oposição por parte de diversos setores sindicais, tanto à direita, quanto ao centro e à esquerda, ela foi emblemática do sentido de conciliação mais profundo presente no primeiro governo de Lula.

As propostas que emergiram das negociações do FNT caminharam na contramão dos princípios que nortearam a criação da CUT, voltados para um sindicalismo independente, desatrelado do Estado que, em boa medida, estiveram na base da constituição do chamado "novo sindicalismo". Além de um conjunto de propostas voltado à flexibilização dos direitos do trabalho, buscou-se, visando beneficiar as cúpulas sindicais em detrimento das bases operárias, transferir para as centrais e suas direções o exercício de negociação, restringindo a ação dos sindicatos e das assembleias de base. 
Mais ainda, as centrais passariam a ser mensuradas e definidas pela sua representação, dificultando a vida organizativa de entidades mais autônomas, uma vez que o proposto passou a contemplar limites mínimos para o reconhecimento da representação dos sindicatos. Por fim, estabelecia que a cobrança do Imposto Sindical e demais contribuições ou taxas assistenciais seriam substituídas pela denominada "Contribuição de Negociação Coletiva" (de até 1\% da renda líquida do trabalhador no ano anterior), obstando diretamente a vontade de cotização autônoma, livre e voluntária dos trabalhadores para a manutenção dos sindicatos (ANTUNES, 2006b; SANTANA, 2009).

Vale destacar sobre esse processo, que marca o início do primeiro governo Lula, que o verticalismo sindical, as práticas cupulistas e o excessivo burocratismo, que a CUT tanto criticou durante seus primeiros anos de existência, encontravam-se impregnados nesta proposta de reforma sindical tanto por meio da tentativa de redução significativa do que ainda se preservava de organização sindical de base, como pelo abandono do tripé liberdade, autonomia e independência sindical, princípios norteadores do chamado "novo sindicalismo" e, por isso, considerados vitais e inegociáveis em sua origem (ANTUNES; SILVA, 2015; ANTUNES; SANTANA, 2014).

Fruto da polêmica e resistência gerada no interior do movimento sindical, não se avançou na tentativa de restrição da participação dos sindicatos e assembleias de base nos processos de negociação. Mas parte das medidas acabou sendo contemplada pela Lei 11.648, de 2008, que legalizou as centrais sindicais brasileiras, estabelecendo os requisitos para que fossem reconhecidas oficialmente. A Lei também estabeleceu, por meio de alteração na CLT, novos critérios de distribuição do Imposto Sindical de forma a contemplar as centrais.

É relevante também demarcar o contexto no qual se desenvolveu a nova política de controle do sindicalismo e seu sentido dúplice. Por um lado, a cúpula sindical passou a ocupar, durante o governo Lula, importantes cargos na alta burocracia estatal (nos ministérios, nos conselhos de empresas estatais e também de empresas privatizadas). Por outro, a incorporação das centrais à estrutura sindical oficial viabilizou tanto a integração dessas entidades ao Conselho Deliberativo do Fundo de Amparo ao Trabalhador (CODEFAT), órgão tripartite responsável pela gestão do Fundo de Amparo ao Trabalhador (FAT), como o recebimento de recursos vinculados diretamente ao FAT ou a outros fundos estatais. Tais mecanismos, frente a um cenário marcado pela unicidade sindical na base e pelo pluralismo sindical nas cúpulas, fortaleceram e aproximaram ainda mais as principais centrais sindicais do governo Lula. 
O universo sindical também se alterou significativamente entre o primeiro e o segundo governo Lula, sofrendo uma forte reconfiguração. Além da CUT, da CTB (Central dos Trabalhadores e Trabalhadoras do Brasil), ${ }^{7}$ da Força Sindical, fundada em 1991, de perfil ideológico à direita, mas integrante da base de apoio sindical do governo Lula, o espectro sindical englobava também outras pequenas centrais que procuravam ampliar seu espaço, como a CGTB (Central Geral dos Trabalhadores do Brasil), a UGT (União Geral dos Trabalhadores), a Nova Central, algumas delas com pequeno nível de representação sindical, herdeiras que eram do "velho sindicalismo" atrelado ao Estado e que viam na aproximação com o governo a possibilidade de ampliação dos recursos e das verbas estatais.

Posteriormente, em oposição aberta aos governos Lula e Dilma, organiza-se a CONLUTAS (Coordenação Nacional de Lutas), entidade fundada em 2004 que, em 2010, passou a denominar-se CSP-Conlutas (Central Sindical e Popular). Foi parte do mesmo processo o nascimento do movimento denominado INTERSINDICAL, com origem em 2006, e que depois se dividiu em duas vertentes. Essas correntes sindicais, ao contrário da totalidade das demais anteriormente citadas, recusavam qualquer tipo de recurso oriundo do "velho sindicalismo" de Estado.

Não à toa, elas vão se constituindo nos primeiros anos do governo Lula, tendo como base entidades sindicais que rompem com a CUT e se posicionam em oposição ao governo do PT. É parte desse processo a adesão às novas centrais, sobretudo à CSP-Conlutas, de um número expressivo de sindicatos ligados ao funcionalismo público federal, cuja base foi fortemente atingida pela reforma da previdência e a chamada reforma universitária, encaminhada por Lula no início de seu primeiro mandato presidencial.

Para além da postura de oposição ao governo do PT e do resgate da independência das entidades sindicais frente ao Estado, outras características dessas centrais merecem atenção. A primeira, a CSP-Conlutas, defende, desde sua origem, a constituição de uma central que aglutine não somente as entidades sindicais tradicionais, mas também as oposições sindicais, as organizações da juventude, os movimentos populares, assim como aqueles constituídos em torno da luta contra a opressão das mulheres, negros e negras, LGBT, etc. Busca, dessa forma, converter-se em instrumento de luta capaz de aglutinar e representar uma parcela da classe trabalhadora cada vez mais complexa e hetero-

\footnotetext{
${ }^{7}$ Formada em sua origem pela Corrente Sindical Classista, que se desfiliou da CUT em 2007 para criar sua própria central.
} 
gênea, fruto do impacto do neoliberalismo e do processo de reestruturação produtiva sobre o mundo do trabalho.

A segunda variante, a INTERSINDICAL, com um perfil mais acentuadamente sindical, buscou resgatar os princípios de um "sindicalismo pela base", encontrando-se, entretanto, claramente dividida entre a criação ou não de uma nova central.

Em todo este quadro de reconfiguração, merece nota a trajetória da CUT e sua transformação de Central sindical crítica e independente dos governos em uma entidade fortemente afinada com as ações e políticas do governo Lula. ${ }^{8}$ Tal reposicionamento apenas serviu, mais uma vez, para desorientar o movimento sindical no combate e oposição ao neoliberalismo, então em sua nova variante social-liberal.

Realizando um significativo deslocamento dos interesses históricos da classe trabalhadora para a defesa de uma ação mais negocial e de pactuação, a CUT distanciou-se de seu projeto sindical e político original, que foi desaparecendo progressivamente das propostas e das ações da Central. Mais complicado ainda foi o fato de que, ao agir desse modo, acabou enfraquecendo a luta sindical e despreparando os trabalhadores para ações sindicais de resistência e confronto.

Apesar de ter sido combatido pela CUT durante anos, o sindicalismo de Estado dava sinais de forte revitalização, adicionado a um componente propositivo. O mundo negocial, a dependência estatal (política, ideológica e financeira) e a política de conciliação de classes sob o comando de Lula, tornaram-se ainda mais intensos, distanciando o movimento sindical daquele que, no passado recente, havia sido positivamente designado como "novo sindicalismo", aproximando-o de uma espécie de sindicalismo negocial de Estado (ANTUNES; SILVA, 2015).

Conforme salienta Braga (2015), “[...] o sindicalismo lulista transformou-se não apenas em um ativo administrador do Estado burguês, mas em um ator-chave da arbitragem do próprio investimento capitalista no país". Preocupada com a rentabilidade dos fundos que passou a administrar, tal como bem assinalou Francisco de Oliveira (2008), e com seus integrantes ocupando postos variados na estrutura do Estado brasileiro, a alta burocracia sindical "financeiri-

\footnotetext{
${ }^{8}$ Não deixa de ser sintomático dessa nova postura política adotada pela CUT o fato de seu expresidente Luiz Marinho, componente da Articulação Sindical, ser alçado à condição de ministro do Trabalho do governo Lula entre junho de 2005 a março de 2007, deixando o cargo para assumir o Ministério da Previdência Social até junho de 2008.
} 
zou-se", isto é, associou seus interesses, enquanto camada social privilegiada, ao ciclo de acumulação do capital financeiro que se desenvolvia. Desta forma, o petismo militante das greves e dos movimentos sociais dos anos 1980 e parte dos anos 1990, afastou-se de suas origens, tornando-se um sócio menor do bloco do poder capitalista no Brasil (BRAGA, 2015).

\section{As políticas sociais e a nova base social de sustentação}

A atuação dos governos do PT manteve certa centralidade em termos de ações dos programas sociais que pudessem ter impactos efetivos na redução da pobreza. E isto foi sentido ao longo do tempo.

O trabalho dos jovens serviu como um dos balizadores da ação do governo em seu início. Lançado em 2003, o Programa Primeiro Emprego, contudo, não atingiu as metas esperadas, sofrendo desativação em 2006. Já quanto à erradicação do trabalho em condições análogas ao de escravo, o governo Lula continuou com as medidas já empreendidas no governo anterior, conseguindo alguns avanços positivos. Por outro lado, os Programas como o Fome Zero e o Bolsa Família9 foram marcas importantes dos governos do PT, com efeitos de relevo, principalmente no segundo caso.

Ao final de seu primeiro mandato, Lula realizou alterações importantes em suas políticas sociais na busca por reconquistar um apoio que estava sendo erodido, principalmente, em função da profunda crise política aberta com o chamado "Mensalão", o que poderia impor riscos à sua reeleição, em 2006 (ANTUNES, 2006a).

Uma das alterações mais expressivas deu-se com expansão do BolsaFamília. Duras e distintas críticas foram dirigidas ao PBF, especialmente pela es querda, no sentido de que este apresentava um eixo meramente assistencialista, sem fornecer alternativa que mudasse a estrutura da miséria brasileira, que poderia ser feita, por exemplo, através de uma reforma agrária profunda, ou pela taxação do capital financeiro e das grandes fortunas, etc.

Se as críticas mais conservadoras justificavam que, ao receber o auxílio do governo, os auxiliados deixariam de procurar emprego, os defensores do

9 Este programa baseia-se na transferência de renda a partir do cumprimento de certas condições. Visando à integração e unificação de programas já vigentes no governo anterior, o Bolsa Família consiste na ajuda financeira por parte do governo às famílias de baixa renda. Estas são definidas ao aferirem renda per capita de $\mathrm{R} \$ 10,00$ a $\mathrm{R} \$ 1.520,00$. Para fazerem jus ao auxílio, as famílias necessitam manter seus filhos e/ou dependentes com frequência escolar e atualizados em termos de vacinação. 
projeto assinalaram que, além de retirar muitos da situação de pobreza, a Bolsa Família garantia indiretamente que os mesmos pudessem também barganhar entrada no mercado em situação menos precária.

A origem do Programa em âmbito nacional remonta da unificação e aprimoramento de "ações de transferência de renda" já desenvolvidas sob o governo FHC. ${ }^{10}$ Trata-se de um Programa que, ao longo do governo Lula, passou a ter alta repercussão entre as camadas mais pobres da população brasileira, com baixíssimo custo para o orçamento público brasileiro quando comparado ao volume destinado ao pagamento dos juros da dívida pública junto aos bancos. Conforme demonstram os dados de 2008, apurados pelo Instituto de Pesquisa Econômica Aplicada (IPEA), “[...] o custo do PBF representa apenas $0,38 \%$ do PIB e cerca de apenas 3\% do total de gastos com benefícios previdenciários e assistenciais do país" (POCHMANN, 2010, p. 8).

O Programa tinha como meta atingir os $20 \%$ mais pobres da população brasileira, elegendo como prioridade a faixa dos $10 \%$. Visava, dessa forma, impactar os indicadores de desigualdade por meio da eliminação do chamado "excesso de desigualdade". Este "excesso de desigualdade", por sua vez, foi identificado a partir da comparação entre indicadores de apropriação de renda de países considerados com nível de desenvolvimento similar ao brasileiro (BARROS; CARVALHO; MENDONÇA, 2010).

Em 2006, ano que marca o fim do primeiro mandato presidencial de Lula, o PBF, ampliou sua abrangência, passando das 3,6 milhões de famílias ${ }^{11}$ atingidas diretamente pelo Programa em janeiro de 2004, para 11 milhões de famílias. O número de famílias atendidas manteve-se estável nos anos de 2007 e 2008, sendo novamente ampliado ao longo de 2009, quando passou a abarcar 13,7 milhões de famílias (SOARES; SÁTYRO, 2010). Os dados relativos ao número de pessoas atendidas pelo Programa, no entanto, fornecem uma melhor dimensão de sua repercussão. Conforme, o estudo realizado por Costanzi e Fagundes (2010, p. 264),

\footnotetext{
${ }^{10}$ Este programa, criado em 2003, substituiu o Programa Comunidade Solidária, instituído no governo FHC, em 1995, no sentido de combater a fome e a miséria, no que seriam suas bases estruturais. Segundo dados oficiais, à época da criação do programa, existiam cerca de 44 milhões de pessoas enfrentando a fome.

11 Outras 4,2 milhões de famílias, em janeiro de 2004, eram ainda beneficiárias de programas remanescentes do governo anterior, como Bolsa Escola, Bolsa Alimentação ou Cartão Alimentação. O PBF foi ao longo dos anos, por meio de um cadastro único, agrupando diferentes benefícios de acordo com o perfil familiar, o que resultou na eliminação destes outros programas. Em 2008, apenas cerca de 15 mil famílias eram beneficiárias dos antigos programas.
} 
Em março de 2010, o número de pessoas que estavam no Bolsa Família chegou a 48,680 milhões. Levando-se em consideração a estimativa de população, em 2009, de 191,480 milhões, significa que o PBF atendia cerca de um quarto da população total do país $(25,4 \%)$. Este percentual variava de $14,9 \%$, no Sudeste (o menor valor), até 45,6\%, no Nordeste (o maior valor). [...] a maior cobertura do programa em relação à população total se dá, em especial, nos municípios das regiões Norte e Nordeste, embora existam cidades com elevada cobertura nas demais regiões.

Esta política social de corte assistencialista, que se constituiu na principal bandeira do governo do PT, foi considerada exemplar pelo Banco Mundial. Voltada menos para a classe trabalhadora organizada, base social de origem de Lula, o Programa passou a atingir os setores mais pauperizados, normalmente mais dependentes do auxílio do Estado para sobreviver.

Os dados de 2010, obtidos por meio do Cadastro Único, sistema de controle e cruzamento dos beneficiários de programas sociais do governo federal, mostram que o perfil dos beneficiários do PBF vai ao encontro do perfil geral da desigualdade social brasileira, que reserva os espaços de maior pobreza à população afrodescendente, às mulheres e aos jovens. Em todas as regiões do país, a participação feminina entre os beneficiários era, em abril de 2010, de $54,2 \%$. Esse índice torna-se ainda mais preponderante se considerado o responsável legal da família. Neste caso, 92,5\% são mulheres. Estes responsáveis, por sua vez, concentram-se na faixa etária dos 25 aos 34 anos $(35,5 \%)$ e na dos 35 aos 44 anos (29,5\%) (COSTANZI; FAGUNDES, 2010).

Quando o olhar se volta para o recorte étnico-racial, os dados apontam para uma população atendida composta fundamentalmente por afrodescendentes, com $65,3 \%$ de autodeclarados pardos e outros 7,5\% de negros, perfazendo um total de 72,8\%. Os dados de abril de 2010 apontam também para a baixa escolaridade dos beneficiários do Programa, com 81,1\% sem ensino fundamental completo, entre eles, $15,8 \%$ de analfabetos (idem).

Os valores recebidos pelas famílias beneficiadas pelo PBF variam. O mínimo, denominado "benefício básico", atualizado em julho de 2016, corresponde a $\mathrm{R} \$ 85,00$. A este valor podem ser acrescidos outros benefícios, considerados variáveis, no valor de $\mathrm{R} \$ 39,00$ cada. Entretanto, apesar do baixo custo, ao abranger $1 / 4$ da população brasileira abaixo da linha da pobreza, o Programa impactou de forma importante tanto do ponto de vista econômico, fornecendo pouco para quem não tem praticamente nada, como político, conformando por anos uma base social fundamental do ponto de vista eleitoral. 
Atuando na mesma direção, conforme já indicamos acima, a ação governamental de aumento real do salário mínimo, ainda que os reajustes o mantivessem muito aquém dos patamares previstos na Constituição e defendidos pelo DIEESE, incidiu sobre os segmentos mais pobres da população, atingindo ramificações mais amplas e extremas no mundo do trabalho.

Fica evidente que, tais ações consolidavam uma migração importante em parte da base social do segundo governo Lula, da classe trabalhadora mais organizada, base original do PT, em direção aos assalariados mais empobrecidos, com menor nível ou mesmo sem organização sindical e política, e que se encontram em áreas menos industrializadas do país (ANTUNES, 2006a). ${ }^{12}$

\section{Os governos Dilma: da ascensão à crise}

O governo Dilma, empossado em 2011, manteve basicamente o receituário econômico do segundo governo Lula: crescimento econômico direcionado ao mercado interno; incentivo à produção de commodities para a exportação; redução de tributos voltados a atender às demandas de distintas frações do capital, como a industrial, da construção civil, etc. Preservou também a política financeira baseada nos juros elevados, garantindo assim, em boa parte de seu primeiro governo, o respaldo do capital financeiro. Foi somente quando as repercussões da crise internacional se acentuaram no Brasil, sendo sentidas não mais como "uma marolinha", que o governo Dilma ensaiou uma política de redução de juros, através dos bancos estatais. Todo este conjunto constituía a chamada Nova Matriz Econômica.

No entanto, o agravamento da crise econômica internacional, que não mais se restringia aos países do Norte, mas que também passou a afetar diretamente os chamados BRICS, foi minando lentamente a base social burguesa que sustentou os governos de Lula e Dilma. Além deste ponto central, outro componente aumentava as cisões e fraturas em relação ao governo Dilma: 1) na cena política, a ação judicial denominada "Operação Lava Jato" envolvia diretamente o PT e seu principal aliado, o velho PMDB, em novos escândalos de corrupção; 2) no universo social, aumentava o descontentamento em relação aos limites do projeto do governo e seu distanciamento cada vez maior dos movi-

\footnotetext{
12 Uma análise das eleições municipais de 2016, a partir desta perspectiva, indica que, apesar da derrota massiva do PT (queda nacional de 60\% de suas prefeituras), ele teve maior possibilidade de resistência exatamente nos espaços de maior penetração do PBF (queda de 28\%) (MELLO; CARRIELLO; GRILLO, 2016).
} 
mentos sociais e sindicatos que compunham originariamente a base social do PT (ANTUNES, 2015).

Essas fissuras do projeto que estruturou os governos do PT não tardariam a levar às ruas os segmentos da juventude trabalhadora mais precarizada. Apesar da ampliação dos empregos, estes postos, reservados majoritariamente às mulheres, jovens e negros, acentuaram ainda mais a lógica perversa que lastreia o mercado de trabalho brasileiro há tempos: as baixas remunerações e sua incidência entre aqueles segmentos tradicionalmente mais discriminados no mercado de trabalho (BRAGA, 2013, 2015).

Foi nesta contextualidade política que, em 2013, explodiram as rebeliões de junho. Quais foram, então, seus principais elementos causais?

Sabemos que as rebeliões de junho se originaram a partir das ações preparadas, em longo período e em várias capitais do país, pelo Movimento Passe Livre (MPL). Estas ações, que tinham como motivação inicial a defesa do passe livre estudantil, aos poucos passaram a abarcar a luta contra o aumento das tarifas do transporte coletivo e em defesa da mobilidade urbana. Em 2013, entretanto, estas manifestações foram ampliadas exponencialmente, passando a incorporar uma gama variada de bandeiras e reivindicações.

Talvez possamos sublinhar que as rebeliões encontraram suas causas de fundo em uma conjuntura especial, na qual convergiram elementos estruturais mais amplos e o afloramento de uma crise política que estava latente. O entroncamento entre estes pontos gerou a combustão que levou às mobilizações que tornaram perceptível o esgotamento do projeto petista.

A jovem população trabalhadora que esteve presente e foi dominante nas praças públicas denunciava o transporte privado e caótico; a saúde pública degradada, e o ensino público abandonado. Rebelava-se, de alguma maneira, contra a mercadorização da sua vida cotidiana.

As manifestações ocorreram, ainda, em uma conjuntura especial, marcada pela organização da Copa das Confederações, momento em que o uso de recursos públicos para interesses privados vinculados à construção de estádios (as denominadas arenas), a todo complexo transnacional e das grandes corporações envolvidas com o entertainment futebolístico, permitiu aflorar uma simbiose profunda entre a FIFA, o governo Dilma, as corporações transnacionais e as diversas frações burguesas articuladas com o governo, em um momento de agravamento da crise.

Este cenário configurou-se de forma ainda mais explosiva, uma vez que vivenciávamos um contexto internacional também caracterizado por rebeli- 
ões, no qual as massas populares se apropriavam do espaço público, exercitando práticas plebiscitárias, horizontalizadas, contrárias às organizações tradicionais, manifestando frontal oposição quanto às formas de representação e de institucionalidade vigentes, quer nos países capitalistas do Ocidente, quer nas ditaduras que se perpetuavam no Oriente Médio.

Estas manifestações, que se prolongaram por longo período, foram polimorfas e policlassistas. Iniciaram-se com forte presença popular, em particular dos estudantes-que-trabalham ou dos trabalhadores-que-estudam, juntamente com setores mais politizados da juventude, dos movimentos sociais urbanos ou das periferias, com partidos de esquerda, sindicatos e outros grupamentos sociais e políticos.

Atingiram também amplos contingentes das classes baixa, média e alta, além de apoio de frações dominantes, na medida em que as manifestações passavam a ter uma presença forte de setores mais conservadores, aparentemente apolíticos, com acento ideológico mais à direita. Entretanto, se estes contingentes não conduziram as manifestações de $2013,{ }^{13}$ eles rapidamente desenvolveram campanhas sistemáticas contra as esquerdas e os movimentos sociais, e particularmente contra Dilma, Lula e o PT. Tudo isso criou os condicionantes que indicavam que essa nova fase crítica seria a de maior profundidade até então vivenciada pelo governo Dilma e pelos governos anteriores do PT.

\section{Uma onda de greves e rebeliões}

O ano de 2013 não foi marcado somente pelas grandes mobilizações de rua. Ao longo deste ano a classe trabalhadora brasileira protagonizou uma onda grevista inédita na história do país. Ao todo, segundo estudo realizado pelo DIEESE (2015), foram registradas 2.050 greves, o que significou um crescimento de 134\% em relação ao ano anterior, quando ocorreram 877 greves.

Outro dado relevante identificado pelo estudo diz respeito à incidência de greves desencadeadas em empresas privadas. Em 2013, as paralisações neste setor superaram em quantidade as deflagradas no setor público, equivalendo a $54 \%$ do total. Essas greves, com participação importante de trabalhadores e trabalhadoras do setor de serviços, caracterizaram-se em grande medida por sua natureza defensiva, ou seja, com pautas relacionadas à “[...] defesa de condições de trabalho vigentes, [...] respeito a condições mínimas de trabalho, saúde e se-

${ }^{13}$ Ver o significativo conjunto de artigos sobre as rebeliões de junho em Sampaio Jr. (2014). 
gurança ou contra o descumprimento de direitos estabelecidos em acordo, convenção coletiva ou legislação" (DIEESE, 2015, p. 8).

Segundo ainda dados do DIEESE (2015, p. 10), em termos do número de paralisações, bem como, as causas principais que foram responsáveis pela eclosão deste expressivo movimento grevista em 2012 e 2013, de cerca de 2.900 greves, vemos que demandas relacionadas ao reajuste de salários (41\% em 2012 e 36\% em 2013), alimentação ( $2 \%$ em 2012 e $27 \%$ em 2013) e condições de trabalho (15\% em 2012 e $21 \%$ em 2013), situam-se entre as três primeiras.

A importância assumida por demandas relativas às condições de trabalho, a terceira reivindicação mais presente entre as greves de 2013, é indicadora do avanço dos mecanismos de precarização entre a classe trabalhadora brasileira. No caso específico do funcionalismo público e dos trabalhadores de empresas estatais, demandas dessa natureza aparecem ao lado de reivindicações relativas à contratação de mais funcionários ou ainda daquelas relacionadas ao cumprimento ou instituição de Plano de Cargos e Salários (DIEESE, 2015).

O ano de 2013 configurou-se, nesse sentido, como o momento que, em meio à crise social aberta, eclodiu, juntamente com as mobilizações de rua, um amplo movimento grevista expresso em formas diferenciadas. Por vezes, as ações abrangeram categorias profissionais de amplitude nacional, como as paralisações desencadeadas pelos bancários. Em outras ocasiões, essas mobilizações também tiveram a marca das greves curtas, por locais de trabalho, podendo contar ou não com a liderança dos sindicatos. A greve dos garis, no Rio de Janeiro, em março de 2014, talvez tenha sido uma das mais emblemáticas do período aberto em 2013.

Dessa forma, ao contrário de uma pretensa inação da classe trabalhadora, evidenciou-se que, as greves marcaram sua presença no descontentamento social e político que varreu o período. Lembremos, só para ficarmos nesta conjuntura, que desde 2012 assistimos à eclosão de diversos movimentos grevistas importantes como, por exemplo, em Rondônia, dos operários nas obras das Usinas de Jirau e Santo Antônio (2012) e, no Rio de Janeiro, dos Rodoviários (2014), dos operários nas obras do Complexo Petroquímico do Rio de Janeiro (2015) e dos Garis (2015).

Digno de nota é que estes movimentos, com marcada presença da juventude trabalhadora precarizada, se fizeram para além das direções sindicais, e que, dependendo da situação, as empurrou, atropelou ou ultrapassou. Há várias indicações de descompassos que, diante de uma certa paralisia da cúpula sindi- 
cal, separou direções e bases sindicais, tanto nas reivindicações, quanto nas formas e dinâmicas de luta.

O projeto lulista, em curso havia uma década, demonstrava sua fadiga e começava a entrar em colapso. De professores públicos a garis, de bancários a metalúrgicos, de trabalhadores da saúde e do transporte aos terceirizados, enfim, uma miríade de categorias assalariadas irrompeu este novo ciclo grevista que, de algum modo, expressou descontentamento em relação às condições precárias de trabalho e salário, a luta por ampliação de conquistas já asseguradas, ou ainda a solidariedade a outras categorias, somando-se aos protestos mais amplos que estavam presentes na cena social e política do país.

\section{Da crise ao golpe: a conciliação exaurida e a contrarrevo- lução preventiva avança}

Foi neste quadro crítico que o governo Dilma chegou às eleições de outubro de 2014, quando a intensidade da crise econômica dava evidências de forte acentuação. Vitorioso, não sem uma disputa acirrada, seu segundo governo, iniciado em janeiro de 2015, curvou-se muito rapidamente às novas exigências das distintas frações do capital, que começavam a dar sinais ainda maiores de dissensão em relação ao governo. O pacto policlassista, arquitetado por Lula e sustentado pelo PT, estava chegando ao fim.

Buscando evitar que esse movimento se expandisse, Dilma ampliou o superávit primário; incentivou novas privatizações em aeroportos, portos, estradas, etc; aumentou a taxa de juros; implementou um ajuste fiscal que penalizou duramente a classe trabalhadora, assumindo publicamente bandeiras - como a reforma da previdência - que eram cada vez mais exigidas pelas classes dominantes.

Por outro lado, pouco depois da vitória eleitoral, em meio ao crescente descontentamento popular, à ampliação do trabalho precarizado e do desemprego, Dilma alterou as regras para concessão do seguro-desemprego, aumentando o prazo de trabalho ininterrupto mínimo (de 6 para 12 meses) para obtenção do benefício pela primeira vez, e ampliando-o também nos casos de novas solicitações. Se isso não bastasse, promoveu alterações nos critérios de concessão de pensão por morte, sinalizando claramente que o ônus da crise seria, uma vez mais, pago pela classe trabalhadora. 
Em junho de 2016, quando o quadro que desenhava o impeachment de Dilma parecia irreversível, o desemprego já atingia 11,5 milhões de trabalhadores. A taxa de desemprego ${ }^{14}$ saltou, conforme o IBGE, dos 6,5\%, no quarto trimestre de 2014, para 9,5\% no primeiro trimestre de $2015,{ }^{15}$ atingindo, em junho de 2016, os 11,3\%. Junto com a ampliação do desemprego, a classe trabalhadora assistiu à forte deterioração de seus rendimentos, em queda de $4,2 \%$, se comparados ao apurado entre abril e junho de 2015, com valores médios aproximando-se, apesar da inflação, dos praticados há três anos e meio atrás.

Com o agravamento da crise internacional, sua forte repercussão no Brasil e a consequente queda vertiginosa do preço das commodities - que se converteram em um dos pilares da economia brasileira, as diferentes frações burguesas, que anteriormente respaldavam os governos do PT, começaram a abandonar o projeto. Assim, além de penalizar ainda mais duramente os assalariados, o governo Dilma se viu submerso em uma forte disputa intraburguesa, uma vez que, neste contexto de crise, ampliaram-se as disputas em torno de quem perderia menos com a redução de lucros decorrentes do quadro econômico. Este quadro de instabilidade foi também enormemente ampliado pela deflagração da Operação Lava Jato, que empurrou o governo Dilma para uma situação que a levou para o desfecho final do impeachment.

Em 31 de agosto de 2016 o Senado Federal pôs o último ponto no enredo que destituiu Dilma Rousseff e o PT do poder, ocupado por 14 anos. Frente ao avanço da crise e da Operação Lava Jato, o PMDB, até recentemente aliado preferencial do PT no governo, preferiu o caminho da conspiração, liderando o golpe de feição parlamentar. Em um dos momentos mais deprimentes da história do Parlamento no Brasil, o vice-presidente eleito, Michel Temer, substituiu Dilma Rousseff, tornando-se presidente de forma ilegítima. Enquanto o cenário econômico foi favorável, o Brasil parecia caminhar bem, mas com o agravamento da crise econômica, social, política e institucional, e, judicial-

\footnotetext{
${ }^{14}$ Em meio ao crescente desemprego, a partir de julho 2015, passou a vigorar o Programa de Proteção ao Emprego (PPE), instituído por medida provisória pelo governo Dilma. A medida, considerada emergencial e convertida na Lei 13.189, possibilitou que empresas, mediante a alegação de dificuldades financeiras e por meio de acordo coletivo, reduzissem jornada e salários em até $30 \%$. Parte da perda salarial dos trabalhadores (50\%), conforme previsto na Lei, seria compensada com verba do FAT. Empresas como a Mercedes Benz, que ao longo de quase duas décadas foram beneficiadas com a redução de impostos, batendo constantes recordes de produtividade e vendas, firmaram acordos dessa natureza. Em agosto de 2016, antes que o acordo chegasse ao fim e desrespeitando a estabilidade prevista na legisção do PPE, a automobilística iniciou o processo de demissões. Dias depois, suspendeu-as para firmar um novo acordo, desta vez, voltado à abertura de mais um Programa de Demissão Voluntária (PDV).

15 Indicadores do IBGE / Pnad Contínua (DIEESE, 2016).
} 
mente com o impulso da Operação Lava Jato, que atingiu alguns núcleos de corrupção política que se encontravam no comando do partido e mesmo do governo, o projeto demonstrou suas limitações e desmoronou. Tudo isso reverteu profundamente o "quadro positivo" anterior, rompendo visceralmente a política de pactuação entre as diversas classes e frações de classes que sustentaram por mais de uma década o projeto lulista.

Já nas acirradas eleições de outubro de 2014 era possível perceber uma redução do apoio das frações burguesas ao governo Dilma. A diminuição da taxa de juros realizada em um período curto foi suficiente para dar o "sinal de alerta" aos setores da burguesia rentista. O agravamento do quadro recessivo, por sua vez, antecipou a pressão das frações dominantes que passaram a exigir mudanças profundas na política econômica de modo a ajustar-se ao novo cenário.

Não foi por outro motivo que, imediatamente após a vitória eleitoral de outubro de 2014, Dilma, para acalmar a oposição, constituiu um ministério de coalisão e nomeou Joaquim Levy, representante dos grandes bancos, para o ministério da Fazenda, com a incumbência de realizar um duro "ajuste fiscal". A medida, no entanto, mostrou-se incapaz de aplacar o descontentamento empresarial. Aumentou também os descontentamentos nas classes populares que perceberam que Dilma implementava um programa que criticou durante o processo eleitoral. Nas classes médias, especialmente em seus setores mais conservadores - desde liberais, até defensores da ditadura militar, passando por protofascistas e fascistas - desencadeou-se um verdadeiro ódio ao governo Dilma e ao PT de Lula.

Ao não conseguir atrair estes setores e por ter defendido um programa durante as eleições e aplicado outro, atribuído à direita neoliberal durante o processo eleitoral, Dilma foi acusada de "estelionato eleitoral".

Nas camadas médias baixas, o descontentameno também se ampliou, pois os salários se reduziram, a inflação aumentou e o desemprego atingiu números explosivos. O mito do projeto "neodesenvolvimentista" do governo do PT desmoronou, na exata medida em que a crise atingiu duramente os setores que haviam sido incluídos durante a Era Lula.

Os setores que ainda se encontravam vinculados ao PT, fizeram um enorme esforço para impedir o impeachment, mas o parlamento, de perfil conservador - verdadeiro pântano da política brasileira - já estava majoritariamente imbuído da proposta de destituir o governo Dilma (e do PT) a qualquer preço. 
A base de sustentação do governo no Congresso, após mais de uma década, es tava rompida.

Como o impeachment está previsto na Constituição do Brasil, gestouse a "alternativa ideal" das classes dominantes e suas distintas frações: deflagrar um golpe com aparência legal e constitucional. Um golpe que, contando com o decisivo apoio da grande mídia e de parcelas decisivas do Poder Judiciário, assumiu a feição não de um golpe militar, como em 1964, mas um golpe de novo tipo, parlamentar, com forte respaldo judicial e midiático.

Apesar do governo Dilma, através do ajuste fiscal comandado por Joaquim Levy, procurar implementar as principais exigências das classes dominantes, a amplitude e abrangência da crise as levou a decidir pelo descarte de um governo que sempre lhes fora útil. Naquele contexto de crise profunda, as classes que antes sustentaram os mandatos do PT vislumbraram a real possibilidade de impor um governo "puro" para garantir que todas as ações necessárias para a retomada da expansão burguesa fossem tomadas e, dentre elas, a completa desmontagem dos direitos sociais e do trabalho, conquistadas ao longo de muitas décadas de luta. Criaram-se, desse modo, as condições para uma nova contrarrevolução preventiva no Brasil, para recordar a rica conceitualização de Florestan Fernandes. ${ }^{16}$

Desde o início de seu governo ilegítimo, Temer apresentou seus projetos de austeridade que aprofundavam aqueles anteriormente iniciados por Dilma. Recompondo a volátil base de apoio parlamentar, por um lado, Temer reduziu drasticamente os investimentos em educação, saúde e previdência pública, dando início às reformas trabalhistas, com a finalidade precipua de destruir a Consolidação das Leis do Trabalho, (CLT), criada em 1943; por outro, ampliou sobremaneira os interesses do capital financeiro na condução da política econômica do seu governo.

Vale enfatizar também que, além de seu papel de destaque na destituição da presidente Dilma, o Poder Judiciário brasileiro continua atuando intensa e seletivamente no sentido de reprimir os movimentos sociais e sindicais anticapitalistas, implementando uma legislação de exceção que busca garantir "tranquilidade e paz social" ao novo governo que se denomina como da "Ordem e Progresso".

Os primeiros resultados desta atuação intensa e seletiva puderam ser constatados nas eleições municipais de outubro de 2016, como uma possível

16 FERNANDES, F. A Revolução Burguesa no Brasil. São Paulo: Zahar, 1975. 
medida, com a queda do PT de terceiro maior partido para o décimo lugar. O número de municípios sob seu controle reduziu-se de 630 para 256, o que significa uma queda de quase $60 \%(\mathrm{G} 1,2016)$.

Este percentual de queda praticamente se repetiu no número de votos que os candidatos do PT receberam, quando comparamos com as eleições de 2012. A marca da corrupção, que o PT, por décadas, atribuia aos demais partidos e usava como bandeira, clamando por "ética na política", se voltou contra ele.

Mas é preciso acrescentar que as ações políticas, judiciais e midiáticas que urdiram o golpe e que sustentam o novo governo não alvejaram apenas o PT. Todo o espectro de esquerda foi ou está sendo atingido pelas medidas ultra-conservadoras e mesmo autocráticas.

\section{Conclusão}

A crise que se abateu sobre o segundo governo Dilma (2015/6) atingiu um ponto de ebulição que repercutiu nos vários níveis: político, econômico, social e institucional. Como procuramos indicar, tal situação desdobrou-se de uma complexa conjugação de elementos mais ou menos simultâneos: 1) ampliação da crise econômica internacional e seus efeitos no Brasil, que desmoronou o mito petista do modelo de crescimento baseado nas commodities, na ampliação do consumo e do mercado interno, e na falsa ideia de que o Brasil estaria imune à crise internacional e preparado para qualquer oscilação e adversidade externa; 2) aprofundamento da crise política, quer pela cisão aberta pelas frações dominantes neste novo contexto de crise, quer pelo avanço das denúncias de corrupção envolvendo, uma vez mais, parte da cúpula política e do governo do PT; 3) desestabilização do arco de alianças que dava sustentação ao governo Dilma, com a dissensão aberta pelo PMDB e grande parte da base aliada, desmoronando por completo a base política parlamentar que dava sustentação aos governos do PT, e, por fim; 4) descontentamento popular que se intensificou com as medidas de "ajuste fiscal" do segundo governo Dilma, em 2015, que penalizaram ainda mais a classe trabalhadora, gerando a explosão do desemprego no Brasil.

Por fim, a crise do governo Dilma deve ser compreendida nos marcos do fim do ciclo de um modelo de governo concebido e erigido a partir de uma hábil política de conciliação policlassista, particularmente sob a liderança de Lula, capaz de articular, ao longo de três mandatos consecutivos do PT, profun- 
das concessões aos diferentes setores das classes dominantes, conjuntamente com medidas de redistribuição de renda para os setores mais empobrecidos e pauperizados, além da ampliação da política de salário mínimo, que acarretou tanto o aumento do consumo de bens assalariados, como ampliou significativamente o endividamento da classe trabalhadora.

Vimos também que, assim como houve um aumento efetivo de emprego e ampliação dos postos de trabalho formais, mantiveram-se claros traços de precarização contratual e salarial, altos níveis de rotatividade, convivendo, ainda, com uma enorme expansão do emprego terceirizado.

Deve-se ainda considerar, conforme indicamos anteriormente, a crescente incorporação de segmentos importantes do movimento sindical e popular às estruturas do Estado. Essa integração de parte das direções sindicais aos inúmeros cargos disponíveis nas mais diversas esferas do governo, se por um lado fortaleceu a constituição de um novo setor social dentro do aparelho de Estado, por outro lado funcionou como importante instrumento de freio e de controle às mobilizações sociais e sindicais daquele que no passado recente definiu-se como novo sindicalismo autônomo e independente (ANTUNES; SANTANA, 2014; ANTUNES; SILVA, 2015).

Essa nova forma de ação do novo sindicalismo, agora partícipe do poder, metamorfoseou-se pouco a pouco em uma variante negocial e de conciliação, ajudando a desorganizar a classe trabalhadora brasileira, dificultando quando não impedindo - que os seus setores sindicalmente mais organizados confrontassem alguns dos pilares estruturais que preservam o capitalismo brasileiro, tais como a estrutura concentrada da propriedade rural, os lucros exorbitantes da burguesia (financeira, industrial, agrícola, comercial e de serviços), as grandes fortunas, uma tributação mais progressiva que taxasse majoritariamente as classes burguesas, etc. Nenhuma destas medidas foram sequer iniciadas pelos governos do PT.

Totalmente envolto em uma política aparentemente exitosa de conciliação policlassista, os governos do PT recusaram uma postura minimamente mais confrontacionista. Além dos exemplos acima, pode-se adicionar outro, que teve papel vital no golpe: a discussão sobre a quebra do monopólio dos meios de comunicação privados sequer foi tentada.

Desse modo, o PT, preso ao governo, não incentivou as possibilidades de resistência e avanço da luta social e sindical organizada, não ativou os movimentos sociais que lhe eram próximos e nem buscou articulações com outros que estavam fora da órbita do Partido dos Trabalhadores. E quando tentou fa- 
zer, durante a fase final do impeachment, já era tarde demais. Diante da pesada artilharia que lhe era direcionada, ficou cada vez mais na defensiva, tendo que buscar saídas judiciais e institucionais.

Em 2013, diante das rebeliões que abalaram o Brasil, mostrou-se incapaz de compreendê-las. No segundo turno das eleições de outubro de 2014, o risco de vitória conservadora do PSDB produziu uma intensa mobilização que foi decisiva para a vitória de Dilma. Logo em seguida, deixou-se de lado essa mobilização e Dilma e o PT fizeram um discurso de vitória convidando a oposição à união e, após a posse, seu governo implementou um drástico ajuste fis cal, propugnado pela oposição mais conservadora.

Forjou-se, então, a "alternativa ideal" das classes burguesas. Estavam criadas as condições para a deflagração de um golpe, uma nova variante de golpe já praticada em Honduras e no Paraguai, para o qual era preciso criar um respaldo legal. Foi aí que se desenvolveu uma práxis política caracterizada por um duplo e articulado movimento, caracterizado pela judicialização da política e pela politização da justiça, com o apoio integral das grandes corporações midiáticas.

E, com isso, o Brasil, que parecia seguir um rumo novo e auspicioso, adentrava, uma vez mais, em uma nova fase de profunda regressão, com a finalidade básica de operar um aprofundamento neoliberal muito mais agressivo, com a atribuição de privatizar as empresas estatais que haviam sido preservadas e, de outra parte, destruir em profundidade os direitos do trabalho conquistados ao longo de mais de um século. A vitória eleitoral de Bolsonaro, em 2018, selou esse trágico período e marcou o início de uma segunda fase, então muito mais profunda, da contrarrevolução preventiva no Brasil (ANTUNES, 2020). Mas essa já é outra história.

\section{Referências}

ANTUNES, R. A Desertificação Neoliberal no Brasil: Collor, FHC e Lula. Campinas: Editores Associados, 2004.

Uma esquerda fora do lugar. O governo Lula e os descaminhos do PT. Campinas: Autores Associados, 2006a.

. Construção e desconstrução da legislação social no Brasil. In: ANTU-

NES, R. (Org.). Riqueza e Miséria do Trabalho no Brasil. São Paulo: Boitempo, 2006b. 
. Desenhando a nova morfologia do trabalho no Brasil. Revista de Estudos Avançados, São Paulo, v. 28, n. 81, p. 39-53, ago. 2014. Disponível em: $<$ http://www.scielo.br/scielo.php?script=sci_arttext\&pid=S010340142014000200004\&lng=pt\&nrm=iso >. Acesso em: 30 jul. 2016.

. A fenomenologia da crise brasileira. Revista Lutas Sociais, São Paulo, v. 19, n.35, p. 09-26, jul./dez. 2015.

O privilégio da servidão: o novo proletariado de serviços na era digital. 2. ed. São Paulo: Boitempo, 2020.

ANTUNES, R; BRAGA, R. (Orgs.). Infoproletários: degradação real do trabalho virtual. São Paulo: Boitempo, 2009.

ANTUNES, R.; SANTANA, M. A. The Dilemmas of the New Unionism in Brazil: Breaks and Continuities. Latin American Perspectives, California, v. 41, n. 5, p. 10 21, 2014.

ANTUNES, R.; SILVA, J. Para onde foram os sindicatos? Do sindicalismo de confronto ao sindicalismo negocial. Caderno C R H, Salvador, v. 28, n. 75, p. 511-528, set./dez. 2015.

ANTUNES, R.; SANTANA, M. A.; PRAUN, L. Chronicle of a Defeat Foretold: The PT Administrations from Compromise to the Coup. Latin American Perspectives, v. 46, p. 85-104, 2018.

BARGAS, O.; OLIVEIRA, M. A. É hora da reforma sindical. Teoria e Debate, São Paulo, n. 61, 2005.

BARROS, R. P. de; CARVALHO, M. de; MENDONÇA, R. Dimensionando o Programa Bolsa Família. In: CASTRO, J. A. de; MODESTO, L. (Orgs.). Bolsa família 2003-2010: avanços e desafios. Brasília: Ipea, 2010, p. 349-356.

BRAGA, R. Sob a sombra do precariado. In: MARICATO... [et al.] Cidades Rebeldes: Passe Livre e manifestações que tomaram as ruas do Brasil. São Paulo: Boitempo: Carta Maior, 2013, 79-82.

. Contornos do pós-lulismo. Blog Junho, 25. Out. 2015. Disponível em: < http://blogjunho.com.br/contornos-do-pos-lulismo/>. Acesso em: 03 jan. 2021.

BRASIL. Fórum Nacional do Trabalho. Proposta de Emenda à Constituição: Projeto de Lei de Relações Sindicais. Brasília, DF: Senado, 2005. Disponível em: <http://www3.mte.gov.br/fnt/ PEC_369_de_2005_e_Anteprojeto_de_Reforma_Sindical.pdf $>$. Acesso em: 30 jul. 2016. 
. Fórum Nacional do Trabalho. Resoluções do Relatório Final da Comissão de Sistematização. Brasília, DF: Senado, 2014. MTE. Disponível em: $<$ http://www3.mte.gov.br/fnt/Relatorio_Final_da_Comissao_de_Sistematizacao.pdf>. Acesso em: 30 jul. 2016.

Decreto-Lei n. ${ }^{\circ}$ 5.452, de $1^{\circ}$ de maio de 1943. Aprova a Consolidação das Leis do Trabalho. Disponível em: <http://www.planalto.gov.br/ ccivil_03/Decreto-Lei/Del5452.htm>. Acesso em 30: jul. 2016.

. Lei 9.601, de 21 de janeiro de 1998. Dispõe sobre o contrato de trabalho por prazo determinado e dá outras providências. Diário Oficial da União, Brasília, DF, 1998. Disponível em: < http://www.planalto.gov.br/ccivil_03/ leis/L9601.htm>. Acesso em: 30 jul. 2016.

. Lei 11.648, de 31 de março de 2008. Dispõe sobre o reconhecimento formal das centrais sindicais para os fins que especifica, altera a Consolidação das Leis do Trabalho - CLT. Diário Oficial da União, Brasília, DF, 2008. Disponível em: < http://www.planalto.gov.br/ccivil_03/_Ato2007-2010/2008/ Lei/L11648.htm>. Acesso em: 30 jul. 2016.

. Lei 13.134, de 16 de junho de 2015. Altera as Leis no 7.998, de 11 de janeiro de 1990, que regula o Programa do Seguro-Desemprego e o Abono Salarial e institui o Fundo de Amparo ao Trabalhador (FAT), n ${ }^{\circ} 10.779$, de 25 de novembro de 2003. Diário Oficial da União, Brasília, DF, 2015. Disponível em: <http://www.planalto.gov.br/ccivil_03/_Ato2015-2018/2015/Lei/ L13134.htm>. Acesso em: 30 jul. 2016.

. Lei 11.101, de 9 de fevereiro de 2005. Regula a recuperação judicial, a extrajudicial e a falência do empresário e da sociedade empresária. Diário Oficial da União, Brasília, DF, 2005. Disponível em: < http:/ /www.planalto.gov.br/ccivil_03/_ato2004-2006/2005/lei/111101.htm>. Acesso em: 30 jul. 2016.

. Lei 10.820, de 17 de dezembro de 2003. Dispõe sobre a autorização para desconto de prestações em folha de pagamento, e dá outras providências. Diário Oficial da União, Brasília, DF, 2003. Disponível em: < http://www.planalto.gov.br/ccivil_03/leis/2003/L10.820.htm>. Acesso em: 30 jul. 2016.

CABRAL, B. Lula participa de comício com 50 mil pessoas. O Globo, Rio de Janeiro, 23 out. 2012. Disponível em: <http://oglobo.globo.com/brasil/lulaparticipa-de-comicio-com-50-mil-pessoas-em-fortaleza6501353\#ixzz4PKn768Xc>. Acesso em: 05 nov. 2016. 
COSTANZI, R. N.; FAGUNDES, F. Perfil dos beneficiários do programa bolsa família. In: CASTRO, J. A. de; MODESTO, L. (Orgs.). Bolsa família 20032010: avanços e desafios. Brasília: Ipea, 2010. p. 249-268.

D'AGOSTINO, R.; REIS, T. PSDB conquista 14 prefeituras no $2^{\circ}$ turno e PT, nenhuma. G1, "Caderno" Eleições 2016. .Disponível em: < http://g1.globo.com/politica/eleicoes/2016/blog/eleicao-2016-em-numeros/post/psdb-elege-14-prefeituras-no-2-turno-e-pt-nenhuma.html> Acesso em: 02 nov. 2016.

DAVIS, M. et. al. Cidades Rebeldes. Passe livre e as manifestações que tomaram as ruas do Brasil. São Paulo: Boitempo, 2013.

DIEESE. Balanço das greves de 2013. Estudos e Pesquisas, n. 79, dez. 2015. Disponível em: <http://www.dieese.org.br/balancodasgreves/2013/estPesq79balancogreves2013.pdf>. Acesso em: 30 jul. 2016.

. Boletim Emprego em Pauta. n. 0, maio 2016. Disponível em:

$<$ http://www.dieese.org.br/outraspublicacoes/2016/boletimEmpregoEmPauta.pdf>. Acesso em: 20 jul. 2016.

DIEESE / CUT-Nacional. Terceirização e Desenvolvimento: uma conta que não fecha. Dossiê sobre o impacto da terceirização sobre os trabalhadores e propostas para garantir a igualdade de direitos. Set. 2011. Disponível em: $<$ http://2013.cut.org.br/sistema/ck/files/terceirizacao.PDF> Acesso em: 30 jul. 2016.

DRUCK, M. G. Terceirização: (des)fordizando a fábrica: um estudo crítico do complexo petroquímico. São Paulo: Boitempo, 1999.

. Os sindicatos, os movimentos sociais e o governo Lula: cooptação e resistência. Observatório Social de America Latina, Buenos Aires, ano VI, n. 19, 2006. Disponível em: < http://biblioteca.clacso.edu.ar/ar/libros/osal/ osal19/debatesdruck.pdf>. Acesso em: 03 jan. 2021.

. Trabalho, precarização e resistências. Caderno CRH, Salvador, v. 24, n.spe1, p. 37-57, 2011.

DRUCK, G.; FRANCO, T. (Orgs). A perda da razão social do trabalho: terceirização e precarização. São Paulo: Boitempo, 2007.

FERNANDES, F. A Revolução Burguesa no Brasil. São Paulo: Zahar, 1975. GALVÃO, A. Participação e fragmentação: a prática sindical dos metalúrgicos do ABC nos anos 90. 1996. 166 folhas. Dissertação (Mestrado em Ciências 
Políticas ) - Departamento de Ciência Política do IFCH, Universidade Estadual de Campinas, Campinas, 1996.

. Neoliberalismo e Reforma Trabalhista no Brasil. São Paulo: Ed. Revan/FAPESP, 2007.

KREIN, J. D.; BIAVASCHI, M. de B. Brasil: os movimentos contraditórios da regulação do trabalho dos anos 2000. Cuadernos del Cendes, ano 32, n. 89, p. 47-82, maio/ago. 2015. Disponível em: <http://www.scielo.org.ve/pdf/cdc/ v32n89/art04.pdf> Acesso em: 20 jul. 2016.

MARX, K. O 18 Brumário e cartas a Kugelmann. Rio de Janeiro: Paz e Terra, 1974.

MELLO, B.; CARIELLO, G.; GRILLO, M. Queda do PT foi menor onde Bolsa Família é mais presente. O Globo, Rio de Janeiro, 03 nov. 2016. Disponível em: <http://oglobo.globo.com/brasil/queda-do-pt-foi-menor-onde-bolsafamilia-mais-presente-20403229>. Acesso em: 04 nov. 2016.

MTE. Fórum Nacional do Trabalho. Reforma Sindical e Trabalhista e Afirmação do Diálogo Social. Ministério do Trabalho e do Emprego. Brasília: Mimeo, 2003.

$369 / 05$

. Reforma Sindical-Proposta de Emenda à Constituição - PEC

Anteprojeto de Lei. Ministério do Trabalho e do Emprego. Brasília: Mimeo, 2005.

OLIVEIRA, F. Crítica à razão dualista/O ornitorrinco. São Paulo: Boitempo, 2008.

POCHMANN, M. Apresentação. Instituto de Pesquisa Econômica Aplicada. In: CASTRO, J. A. de; MODESTO, L. (Orgs.). Bolsa família 2003-2010: avanços e desafios. Brasília: Ipea, 2010. p. 8-10.

Nova classe média? O trabalho na base da pirâmide social brasileira. São Paulo: Boitempo, 2012.

PRADELLA, L.; MAROIS, T. Polarising development: alternatives to neoliberalism and the crisis. Pluto Press: London, 2015.

PRAUN, L. A teia do capital: reestruturação produtiva e "gestão da vida" na Volkswagen do Brasil: Planta Anchieta. 2005. 167 folhas . Dissertação (Mestrado em Sociologia- Instituto de Filosofia e Ciências Humanas- IFCH) - Universidade Estadual de ampinas, Campinas, 2005. 
. Reestruturação negociada na Volkswagen: São Bernardo do Campo.

In: ANTUNES, R. (org.). Riqueza e Miséria do Trabalho no Brasil. São Paulo: Boitempo, 2006. p. 155-178.

PRAUN, L. Sindicalismo metalúrgico no ABC Paulista: da contestação à parceria. In:

SAMPAIO Jr., P. Jornadas de Junho. São Paulo: Instituto Caio Prado/ICP, 2014.

SANTANA, M. A. Entre a ruptura e a continuidade: visões da história do movimento sindical brasileiro. Revista Brasileira de Ciências Sociais, São Paulo, v. 14, n. 41, p. 103-120, 1999.

SANTANA, M. A. A estrutura sindical brasileira em tempos de reforma: consensos, dissensos e dúvidas.. In: LEITE, M. de P.; ARAÚJO, A. M. C. (Org.). O Trabalho reconfigurado: ensaios sobre Brasil e México. 1. ed. São Paulo: Annablume, 2009. . Labor, Workers, and Politics in Contemporary Brazil: 1980/2010. In: PEILIN, L.; GORSHKOV, M. K.; SCALON, C.; SHARMA, K. L. (Org.). Social Stratification in the BRIC Countries: Change and Perspective. 1. ed. Singapore :World Scientific Publishing Co, 2012.

SILVA, Luiz Inácio Lula da. Carta ao Provo Brasileiro. São Paulo: Fundação Perseu Abramo, 22 de junho de 2002. Disponível em: < https:// fpabramo.org.br/csbh/wp-content/uploads/sites/3/2017/04/03cartaaopovobrasileiro.pdf>. Acesso em: 03 jan.2020.

SINDICATO DOS METALÚRGICOS DE SÃO BERNARDO DO CAMPO E DIADEMA. Reestruturação do complexo automotivo brasileiro: as propostas dos trabalhadores na Câmara Setorial. São Bernardo do Campo: Editora FG ,1992.

SOARES, S; SÁTYRO, N. O Programa Bolsa Família: desenho institucional e possibilidades futuras. In: CASTRO, J. A. de; MODESTO, L. (Orgs.). Bolsa família 2003-2010: avanços e desafios. Brasília: Ipea, 2010. p. 27-55. SOUTO MAIOR, J. L. Velhas e novas ameaças do neoliberalismo aos direitos trabalhistas. Revista eletrônica do Tribunal Regional do Trabalho da Bahia, Salvador, BA, v. 4, n. 6, p. 145-173, jul. 2015. Disponível em: <http://www.anamatra.org.br/index.php/artigos/velhas-e-novas-ameacas-do-neoliberalismoaos-direitos-trabalhistas>. Acesso em: 20 jul. 2016. 
TRÓPIA, P. V.; SOUZA, D. C. (Orgs). Sindicatos metalúrgicos no Brasil contemporâneo. Belo Horizonte: Fino Traço, 2012. 